\title{
The Potentiality of 'Politics' in Aristotle: The Logos and Meaningful Speech among Men
}

\section{Aristoteleste 'Siyasal'ın Potansiyelliği: Logos ve İnsanlar Arasındaki An- lamlı Konușma

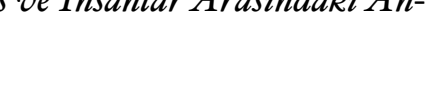

EFE BAȘTÜRK

Recep Tayyip Erdoğan University

Received: 2I.II.20I8| Accepted: 22.0I.20I9

\begin{abstract}
In Aristotelian political philosophy, the basic idea and form of "politics" is structured on a specific "ability" referring to speech. According to Aristotle, man is much more a political animal than the other beings in nature because he has the logos, which refers to "meaningful speech". In this study, I will discuss the Aristotelian political philosophy including the logos and sources of meaningful speech by referring to some arguments that are discussed in his other biological and ethical works. In those works, Aristotle discusses the "ability to speak" in a framework of the structure of the "phone" which is distinguishably connected to political animality in the Politics. For Aristotle, man is more political than other beings because he has natural and intrinsic tendencies that will make him political. The aim of this study is to claim that the political philosophy of Aristotle should be discussed within the arguments of his biological, metaphysical and ethical assumptions.
\end{abstract}

Keywords: Phone, logos, political animal[ity], Aristotle, ethics.

(C) Baștürk, E. (20I9). The Potentiality of 'Politics' in Aristotle: The Logos and Meaningful Speech among Men. Beytulhikme An International fournal of Philosophy, 9 (I), 75-88. 


\section{Introduction}

In Politics, Aristotle discussed a specific and stimulating argument which points out the human under the notion of "political animality". According to Aristotle, the human is one of the political animals in the nature. However, he is distinguished from the other political animals by his "ability to talk" which means that he has an ability to create meaningful speech or logos. At first glance, Aristotle seems to reduce the political being to the ability to talk. However, he actually deepens and opens up these arguments in other texts and discussions. These discussions through different texts are made in an effort to understand the political meaning of the logos which is mostly understood as a linguistic form in Aristotelian philosophy. The aim of this study is to discuss the importance of the logos in Aristotelian political philosophy beyond the point of view that limits it to a linguistic form. The reason why Aristotelian political philosophy is mostly understood with the biological framework belonging to the ability to have the logos is because Aristotle handles politics itself under the form of political animality. However, this idea does not refer to a biological reductionism, because Aristotle does not connect the biological form with politics itself; rather, he aims to handle and conceptualize politics under the conception of a competency process by which the human can complete his existence according to his purpose and nature. So, for him, politics is firstly a matter of competency which refers to an existence in which the human can exceed his own singularity and become a social and political being with the other people in a society. As a result, in Aristotle, politics is not an external category that is thought to be outside the human's biological form and teleological existence.

Aristotle defines the man as a "political animal", but the definition actually says that "the man is much more political" than the other political animals in the nature. In that case it can be clearly understood that Aristotle does not see man as the "only" political being in nature. Therefore, we must firstly resolve why man is handled as "much more political" from the Aristotelian point of view. As we know, the reason why man is much more political than the other political animals is because of his ability to talk. However, this ability refers to a radical distinction with man and the other political animals because man has the ability to create 
meaningful speech (logos) while the other animals can only make sound (psophos). What Aristotle sees at the basis of the political is the meaningful nature of language or speech. Aristotle here makes a critical distinction between voice and parole. The voice refers to a bodily action and includes no meaning; but, on the other hand, the parole is sourced from the phone which comes from an animal and is directed to another animal. Aristotle here distinguishes two types of sound: the first one is the meaningless voice that is limited to itself and not directed to the other. The second one is the meaningful voice which is a request from the other.

This distinction can clearly be seen in Aristotelian political philosophy. As Aristotle emphasizes, politics is a type of existence where the single form of the human being is transformed into the political being by exceeding his simple form of existence. Transforming of man into a political being is seen in biological teleology and this teleology can be found in the Aristotelian linguistic distinction. In this study, an attempt is made to conceptualize the Aristotelian political philosophy through the distinction between the different types of voices. In other words, it is the aim to demonstrate that the meaning of the argument "man is a political animal" can be comprehended better with reference to his biological, metaphysical and ethical theories as well as his political theory.

\section{Aristotelian Problematization on Ability to Speak}

At the beginning of Metaphysics, Aristotle states an argument about the ability to make sounds in bees. ${ }^{\mathrm{I}}$ According to Aristoteles, while bees have the ability to make sounds, they do not have the ability to hear or learn the meaning of the sounds (Aristotle, I991: I-980b23). However, Aristotle himself declares another context about bees in "Parts of Animals". In this text, Aristotle remarks on the movements of bees while they do make sounds during certain movements. Bees make some sounds when they tend to be organized, for example, when they go to work collectively (Aristotle, 1937: IX-40-627a25). Although bees are gathered collectively by the sounds that they can make, Aristotle seeks to clarify the function of the voice in becoming "much more political". We can see this

\footnotetext{
I The bees and birds play an important role in Aristotelian philosophy because Aristotle sees them as political animals in nature because of their ability to organize collectively. $\mathrm{He}$ also mentions bees and their political roles in the Politics.
} 
clarification when Aristotle distinguishes the phone from the voice. In Metaphysics, Aristotle makes a clear distinction between making sounds and hearing voices. Making sounds is a reflex and impulsive movement of bodily existence, whereas hearing voices causes a meaning to be ascribed to what is heard. Moreover, the function of hearing here means that there is an otherness which is called to the voice with a request.

Aristotle defines the ability to hear and listen to the voice (psophos) and he distinguishes this ability from the sound which means the aural reflection of an impact occurring between two separable things. Sound does not include a meaning in the voice because it is the single reflection of a single event. However, the ability to learn means that the voice is shaped in accordance with its reason. In other words, through this transformation, the reason noticed with the voice begins to be understood with the voice linked with it. This is the linking part in which the voice and its reason are combined together. For Aristotle, some birds grow up listening to other birds' warbles and their sounds differ from those of their parents. The reason why they differ from those of their parents is because the listening can shape the intrinsic tendency (Aristotle, I937: IV-9-536b). Why Aristotle correlates the listening and learning is because he thinks that the natural tendency can be shaped or exceeded. The birds can exceed the natural type of their tendencies by imitating (mimesis) (Aristotle, I902: IV-6). Imitation here means the possibility to shape the intrinsic tendency by learning and adapting. Therefore, Aristotle here starts to emphasize the function of the voice in the learning process with the term of the phone. The phone, as Aristotle argues, differs from the voice because the phone occurs with a subjective intervention inside the body (Aristotle, 2002: II-42ObI4). So, the phone actually refers to a combination of the living being with its outside, because the phone cannot be easily reduced to a simple biological function of the body (Aristotle, I937: II-66oa). This shows that the phone radically differs from the sound, because here the voice comes from inside with a subjective organization within the body. As Aristotle describes it, this is the psophos which is the meaningful phone. Unlike the voice, the phone is not a semantic thing, nor is it about physiological matter; rather, it is the voice of the soul but not of the body (Aristotle, 2002: II-420bi5). 
As we can clearly understand in the Aristotelian distinction, while the voice comes from the body and it reflects a natural or impulsive reaction, the phone comes from a subjective and creative intervention which can be connected with the object that is linked with the voice. For example, the borborygmus sound shows the natural process of the body and its hunger. However, saying "I'm hungry" directs the hearer to an object that can be linked with the phone in the saying. So, for Aristotle, single bodily sounds demonstrate the bodily existence of the being, but the phone shows that the being does have a soul which can give a specific meaning to the voice. Or, in other words, the bodily sound comes out without any subjective reason or intervention and is totally singular, whereas the phone comes from inside and it points out that the being cannot attain the objects that it desires with its own purpose. Therefore, the phone illustrates that there is a need for the otherness which may respond to the request. The phone eventually signifies a particular call to the other and this call is an invitation to attain the object that is desired and cannot be obtained by a singular subject. Therefore, the phone is a call for organization to be constructed among living beings.

We can see why Aristotle sets the problem of speech as the basis of the Politics, because the speech coming from the phone can only work in a society in which men can coordinate their own purposes, wishes, desires, etc. with each other. So, the phone is a reflection which necessitates a public negotiation among men in society, because through the phone men can exchange and respond to the requests, calls, invitations, etc. coming from the other. It also illustrates that the phone is the transformation of a particular bodily experience to the common speech. It also points out that the world is experienced commonly, because through the phone men can realize the limits or possibilities that are affirmed by the other members of society. So, by means of the phone we can access the world through the others in order to obtain our needs which cannot be obtained by ourselves. This is the critical point in understanding Aristotelian political philosophy linked with the notion of the ability to speak. Moreover, Aristotle, in the Politics, connects the biological tendency of men with the reason and the substance of the political. 


\section{The Logos and the Substantive Possibility of Becoming a Political Animal}

Before starting to analyze the problematization of political animality in the linguistic context in the Politics, we should firstly emphasize an important insight about phonetic communication in bees and its problematization in Aristotelian philosophy. Aristotle argues that although bees can hear, they cannot hear meaningful sounds (phones). Aristotle's emphasis here is based on the nature of the meaningful voice and he seeks to differentiate bees by mentioning the difference between sounds and phones. What bees can hear is a singular sound that reflects a particular movement in the nature; therefore, no bee can ascribe any meaning to that sound. However, they can listen to the voice and they can obey that voice. The word "obedience" here is very important, as Aristotle argues that obedience is linked with listening, because the Greek word akouein is used in Aristotle's text to point out that obedience to the phone is possible with meaningful listening (Aristotle, I937: IX-6roar7).

So, Aristotle differentiates the voice from the sound once again, but here, he aims to express that the meaning is not an intrinsic part of the speech, but is the result of a subjective production occurring inside the soul. Aristotle figures out this idea from the movement of bees. When bees come back to the hive, they share their experiences with meaningless sounds, but, for Aristotle, it is a meaningful voice because through that voice the experience becomes a common sharing. All of the bees can follow the voice and its message included in the voice and they transform themselves by obeying that sound (Mayhew, I999: I3I). According to Aristotle, the only reason why bees have a queen is that they form a rule by giving a meaning to the voices coming from outside. This is why Aristotle counts bees as political animals.

What does it mean for man to be a political animal? Aristotle begins to discuss the political animality of man at the beginning of the Politics. As Aristotle argues, man is much more political than the other political animals (Aristotle, 1997: 1253a7). Then, he connects this idea to the ability to speak. For Aristotle, man is a much more political animal because he has an ability that no other animal can have. The ability to speak, then, differentiates man from the other types of political animals. The important part for us is where Aristotle constructs this differentiation be- 
tween man and other types of political animals, because Aristotle here discusses this issue by using the term logos which means both "speech" and "reason". So, for Aristotle, becoming a much more political animal depends on "reasonable speech" which cannot be performed by any other political animal. For Miller, only man has moral perception, and more importantly, he has a sense of usefulness and justness and through this, he is the only political animal that can cooperate for a common purpose (Miller, I995: 32). The Logos provides this communication among men, because the logos helps men to organize their complex social relations. The Logos is the reflection of exceeding the basic singularities and of being involved in a complex and mutual relationship system. As we can understand from Aristotle, the logos is the ability to speak; but what does "speech" mean, and why does it differ from phone? For Aristotle, the logos is the possibility to organize the complex social system, because, through the logos, men can determine the principles that exceed the singular context of the particular matter involved in the speech. So, the logos functions so as to determine the principles that can rule any singularity and particularity. The Logos helps men to exceed the singular and daily form of their actions; it means that the logos is the possibility to determine the sempiternal matter that cannot be reduced to changeable singularities.

Aristotle discusses this idea in the Nicomachean Ethics by illustrating that the ability to speak is an existential issue. For him, the experiencing of existence is preferable when a man can realize himself as a virtuous being (Aristotle, 20II: II7OaI3). However, the possibility of this realization depends on accepting the being of the other who can affirm the virtuous existence of the man. According to Aristotle, the most virtuous form of community exists in acts where people can share thoughts through the logos. The Logos, here, demonstrates the higher and noble degree of life, because it is the possibility of attaining the ontology of the common. However, the term "common" does not mean the fact of generality; rather, it means a reconciliation in which different thoughts and singularities are gathered together and then adapted under the notion of the "good". The good, as we know from Aristotle, is the midpoint of the two converse sides, and so, it is a kind of mediation between two irreconcilable converses. The reason why Aristotle handles the logos with the notion of the good is 
because the logos is the mediation path in which the irreconcilable singularities can be mediated with each other. The mediation reflects the being of the other which unifies the particular forms of a linguistic call and brings them under a meaningful speech.

We can comprehend this notion of mediation from the function of the logos, because, through the logos, the difference between useful and useless or just and unjust can be constructed, and so, the logos gains a political meaning because of this. The reason why the logos gains a political meaning is because the political means the collective living among men who should exceed their singular living beings. The possibility of constructing the "political" therefore necessitates a reconciliatory linguistic form through which the difference between the just and the unjust can be distinguished (Cooper, I982: 20I; Cooper, I985: 154). It is also the basis of the political that men - the subjects of politics - can establish an order in which the singular and changeable forms of the facts can be exceeded. Pellegrin interprets this idea as the political form of the logos, because, for Pellegrin, Aristotle handles the linguistic function of the logos as a political tendency of men (Pellegrin, 2012: 565). So, as we can understand through Pellegrin, man is a political animal because he can use the political form of the logos, which is meaningful speech.

Aristotle defines the logos as "a signifying voice, one of whose parts is signifying separately, not as an affirmation, but as an expression" (Aristotle, I938: 6b26-28). The reason why Aristotle handles the logos as an expression is in order to explore the indicative function of the logos. The indicative function refers to a meaning in which both affirmation and negation are included. What Aristotle understands from the meaning is an inclusion of truth and falsity together; therefore, the meaning gains its being because it refers to both affirmation and negation. On the one hand, the meaning refers to an affirmation which points out what should be; on the other hand, it refers to a negation which illustrates what should not be. So, for Aristotle, the logos is not a problem of grammatically correct use of letters or sentences, rather, it is the matter of constructing the indicative notion which refers to an affirmation that can also be corresponded with the intrinsic meaning of the speech. The reason why people can establish the moral and political order through the logos is that 
the logos does not only show an affirmation in the sentence, but it can also be associated with a practice corresponding to the meaning that appears in the sentence. In other words, as the moral and political order necessitates a normative meaning including a contradictive relation between negation and affirmation, only the logos can provide this differentiation because the logos is the only condition whereby the meaning established in the sentence can be related to an external sign. This is why the moral order must be established both grammatically or semantically and practically. So, this shows the indicative function of the logos which refers to the declarative and normative meaning including the affirmative codes within the speech.

Now we can see that the difference between men and the other political animals is not only the ability to talk. More importantly, the Aristotelian differentiation of political animality does not depend on the ability to talk, rather, it depends on the concreteness of the meaning. The principle of concreteness is the construction of a contradiction by which the meaning can be related with practical facts, and so, the normative organization of collective living can be possible by this means.

Why is this contradiction between negation and affirmation so important? Because, for Aristotle, it shows that the linguistic form of the logos is not the only condition for being political. In other words, being political needs much more sophisticated facts compared to the political function of the logos, because Aristotle does not combine the logos with the political itself, rather, he seeks to consider the political itself with the function of the logos. However, the function of the logos is not an intrinsic part of speech; or, in other words, the political function of the logos is outside the sentences. As Aristotle defines, the political is the result of seeking the principal conditions of collective living, and therefore, the logos as the basis of politics must offer a normative meaning that exceeds the singular form of the particular claims about truth. The logos, therefore, can have a political function as it provides access to a universality that exceeds the limited context of singular claims and connects everyone under a normative context. So, the political function of the logos cannot be reduced to the ability to talk because it gains its meaning by exceeding the limited context of talking. 


\section{The Perfection of Man: Ethico-Political Animality through the Logos}

A selective reading of Aristotle's political philosophy leads us to suppose that ethical life precedes political life. This presupposition suggests that we as the mankind can become virtuous living beings by adapting ourselves to public life. Politics, for Aristotle, is the knowledge of this entering or joining of the community that is organized and established by virtuous man according to the principles of morality. The Aristotelian point of view of politics is, then, based on framing the scope of moral life by referencing it to the knowledge of politics. As we can see in the Politics, the knowledge of politics is also the knowledge of making sufficient laws, and these laws should be privileged for ethical life for both public and personal life for the members of political society (Fritz and Kapp, I977: II6-II7). So, it may be argued that what Aristotle understands from politics is the competency of man through public life which is established according to the principles of morality performed in public life.

According to this Aristotelian assumption, Aristotle distinguishes political-public life from his singular-personal life. For him, personal life is an atomistic life zone and it is filled with the necessities that are reduced to the biological existentiality of man. However, public life is about the rules, principles and norms which allow every singular being to be able to live together, exceed his singular necessities and become a competent being. The logos is a matter of public life in which men can attain the universality that exceeds any singular claim about truth. So, as we can see from this idea, the function of the logos is firstly designated by distinguishing the personal and public living forms. However, the importance of this differentiation should be seen in the concreteness which is linked with the normative meaning established in the indicative linguistic form. In other words, the difference between personal life and public life is not established grammatically in a sentence, rather it is constructed according to the concrete meaning of the indicative affirmation in practice. This indicates the political function of the logos which helps to differentiate the notions according to their concrete meanings. Yet these meanings can only be comprehended by the men who are the subjects of the ethico-political life in the city. Because the members of political society can comprehend the differentiations, they can establish the political 
regime according to moral standards. All of these can be made through the logos, because by means of the logos men can comprehend that their singular beings are not sufficient in order to establish a collective community. So, the logos is the opportunity and possibility to exceed the singular being, and, more importantly, to go far beyond the singular egocentric comprehension of the world, because the logos, as we find in Aristotle, is an activity for considering what is beneficial, just and moral; so, it divides the world according to the normative codes including affirmation and negation. By means of this division, man can make living in a community possible. This Aristotelian division also refers to a transformation in which man himself changes into another type of being. As Trott argues, it is a transformation from anthropos to political (Trott, 2010: 293), and we can see that process in the political function of the logos. For Aristotle, being political is a natural tendency of man and, however it may seem like a biological reductionism, Aristotle strongly argues that through the ability to talk - referring to the logos - man can problematize his and others' being in public. As we see in the Politics, "A voice (phone) is signifier of what is pleasant or painful, which is why it is also possessed by the other animals... But speech (logos) is for making clear what is beneficial and harmful." (Aristotle, 1997: 1253a8-18).

As we can see, Aristotle does not only differentiate the logos from phone; he also divides the two types of being: the one is totally singular and can only feel the bodily experiences defined as pleasant or painful. It indicates that these types of experiences cannot be examined by the other being at the same time (for example, when I'm hungry, you cannot examine my hunger; you can examine it only when you are hungry). However, examining beneficialness and morality indicates that these are only experienced collectively, and so, these are possible only if there is a suitable form of living experiencing these according to their collective form. For example, hunger can only be experienced by a singular, bodily form of being - which is called anthropos - however, inequality as a social problem can only be experienced by a collective form of being - which can be called political. So, what we should see in this differentiation is the transformation of body to soul, phone to logos, anthropos to political and egocentric to moral. Aristotle claims that by having the logos, men can have 
the ability to comprehend what is moral and just, which is the formal basis of a community (Sparshott, I994: 47). In the Nicomachean Ethics, Aristotle describes the ability to comprehend with the principle of responsibility against the world, because man can perceive his own being and purpose according to his condition within the world (Aristotle, 2OII: III4b2). Therefore, the man who gives priority to the "good" must firstly take responsibility for the world, because seeking the good is possible only within the world and thus, men should know that the world is the ontological condition of the "good". As Aristotle clearly states; the logos, which makes living possible according to the good beyond the simple form of life, is the basic condition of ethico-political life for a human being in the city (Aristotle, 2OII: I252b29; Aristotle, I997: I274b32I275a34). So, the competence of man can be provided with his ability to have the logos which helps him to be a political animal that can handle his own being within the world, which is shared by the other responsible human beings. The community is therefore handled as a moral and existential matter in Aristotelian political philosophy.

\section{Conclusion}

In Aristotelian political philosophy, the political role and function of the logos cannot be defined only by the linguistic context that it contains. The reason why man is much more a political animal than the other political animals depends on a linguistic ability that transforms the difference between singularity and community life into an ethical distinction which is established through the ability to have the logos. The Logos is therefore not only a linguistic ability to talk, but it is also the fundamental reason for evolving into an ethical being. The Aristotelian distinction between man and animals does not depend on a bodily ability, but rather it depends on whether the being can perceive its existence beyond its singular form or within the community. The function of the logos is to separate the human from its singular being and to make him attain the knowledge that he shares the world with others. The possibility of that knowledge depends on establishing a common sense by which the members of the community can adapt themselves to those normative indicators, and this will be the logos that will enable the members of the community to experience the sense of public consciousness required by the common life. 


\section{References}

Aristotle (1902). The Poetics. (Trans. S. H. Butcher). New York: Macmillan.

Aristotle (1937). Parts of Animals, Movement of Animals, Progression of Animals.

(Trans. A. L. Peck \& E. S. Forster). New York: Harvard University Press.

Aristotle (1938). On Interpretation. (Trans. H. P. Cooke). Cambridge: Harvard University Press.

Aristotle (I99I). Metaphysics. (Trans. J. H. McMahon). New York: Prometheus Books.

Aristotle (1997). Politics. (Trans. P. L. P. Simpson). Chapel Hill: University of North Carolina Press.

Aristotle (2002). De Anima. (Trans. D. W. Hamlyn). Oxford: Clarendon Press.

Aristotle (20II). Nicomachean Ethics. (Trans. R. C. Bartlett \& S. D. Collins). Chicago: University of Chicago Press.

Cooper, J. M. (1982). Aristotle on Natural Teleology. Language and Logos. (Eds. M. Schofield and M. Nussbaum). Cambridge: Cambridge University Press, 197222.

Cooper, J. M. (1985) Hypothetical Necessity. Aristotle on Nature and Living Things. (Ed. A. Gotthelf). Bristol: Mathesis Publications, I50-I67.

Mayhew, R. (1999). King-Bees and Mother-Wasps: A Note on Ideology and Gender in Aristotle's Entomology. Phronesis, 44 (2), I27-I34.

Miller, F. D. (1995). Nature, Fustice and Rights in Aristotle's Politics. Oxford: Clarendon Press.

Pellegrin, P. (2012). Aristotle's Politics. The Oxford Handbook of Aristotle. (Ed. C. Shields). New York: Oxford University Press, 558-589.

Sparshott, F. E. (1994). Taking Life Seriously: A Study of the Argument of the Nicomachean Ethics. Toronto: University of Toronto Press.

Trott, A. M. (2010). Logos and the Political Nature of Anthropos in Aristotle's Politics. Polis, 27 (2), 292-307.

Von Fritz, K. \& Kapp, E. (1977). The Development of Aristotle's Political Philosophy and the Concept of Nature. Articles on Aristotle: Ethics and Politics. (Eds. J. Barnes \& M. Schofield \& R. Sorabji). New York: Duckworth, II3I34. 
Öz: Aristotelesçi siyaset felsefesinde siyasal olanın temel fikri ve biçimi, özel bir “yetenek” biçimi olan konușma üzerine temellenmiștir. Aristoteles’e göre, insan, anlamlı konușma anlamına gelen logos sahibi olduğu için diğer politik hayvanlardan daha politiktir. Bu çalıșmada, diğer biyolojik ve etik çalıșmalarında tartışılan bazı argümanlara atıfta bulunarak, Aristotelesçi politik felsefeyi logos ve anlamlı konușmanın kaynakları üzerinden tartıșacağım. Bu çalıșmalarda Aristoteles, 'konușma yetisi'ni Politika metninde "siyasal hayvanlık” olarak belirtilen durumla bağlantılandırılan "phone" bașlığı altında kullanır. Aristoteles için insan diğer canlılardan daha politiktir, çünkü kendisinde onu politik kılacak doğal bir yatkınlık vardır. Bu çalıșmanın amacı, Aristoteles'in politik felsefesinin biyolojik, metafizik ve etik varsayımlarının dahilinde tartıșılması gerektiğini iddia etmektir.

Anahtar Kelimeler: Phone, logos, siyasal hayvan[lik], Aristoteles, etik. 